\title{
LOS FUTUROS SECRETARIOS E INTERVENTORES DE ADMINISTRACION LOCAL VISITAN EL MUSEO DEL PRADO
}

El día $10^{\circ}$ de mayo tuvo lugar la última de las tres visitas que, organizadas por el Instituto de Estudios de Administración Local, han hecho los alumnos de la primera promoción de Secretarios de primera categoría y la segunda de Interventores de Fondos que cursan sus estudios en dicho Centro.

Fueron hechas estas visitas por iniciativa del profesor de Doctrina Nacional-Sindicalista de la Escuela de Administración Local, señor Aguilar y Paz. Con la entusiasta y documentadísima colaboración del catedrático de la Universidad Central señor Ovejero, recorrieron los alumnos las distintas salas del Museo, admirando las obras maestras del Arte pictórico que allí se encierran.

La visita no pudo ser más emotiva. Evocadora de las páginas más gloriosas de la historia patria. sirvió de motivo a las más profundas meditaciones. Allí, ante el cuadro en que el pintor cordobés Bermejo representó al gran santo español Domingo de Silos, los futuros colaboradores de la obra rectora encomendada a los Municipios españoles rindieron tributo al gran estadista, que, tras de la. más fecunda labor en pro de nuestra Administración local, ofrendó a la Patria el sublime tributo de su vida. Aquel gran tribuno que se llamó don José Calvo Sotelo y que inspirado, como el santo de Silos, por un profundo desprecio hacia lo terreno, supo elevar su espíritu, ofreciendo en pleno Parlamento socialista su vida a España con las mismas palabras de Santo Domingo, inmortalizadas por Berceo en su famoso poema.

Luego la lección de la trilogía velazqueña: Patria. Trabajo y Fafamilia. La Patria representada en el cuadro de "Las Lanzas", maravillosa expresión de la hidalguía de un pueblo que sabe vencer, esto es, que "sabe ganar la guerra y ganar la paz", como tan acerta- 387 
damente decía el profesor Ovejero ante este lienzo. Ante él nos vino a la mente el recuerdo de cierta lápida con que los vencidos del cuadro correspondieron a la hidalguía española de Spínola...

El Trabajo, dignificado en el Arte esplendoroso que se manifiesta en "Las Hilanderas", tiene también su lugar adecuado en la obra del gran pintor, como lo tiene la Familia en el cuadro viviente de "Las Meninas".

Por algo se nos dijo que era el Museo, más que un recuerdo de un pasado glorioso, todo un programa político. Efectivamente, para esta generación que, como Goethe en otro tiempo, vió girar la Historia; para esta generación que sabe lo que es una nueva perspectiva de valores, hay en el Museo del Prado todo un programa de actuación. $Y$ si los que en sus salas meditan son los que van a imprimir un nuevo ritmo a la vida local, no cabe duda que podremos decir que la Revolución está en marcha. Quizá en otros tiempos no se comprendiera que fuese preciso a un Secretario de Ayuntamiento visitar el Museo del Prado; pero hoy, en este momento crucial de la Historia, es el Museo la mejor escuela de lo español; allí se aprende, en el lenguaje mudo del Arte, que si lo germánico es lo real y lo italiano la belleza, lo patrio es la vitalidad; cómo frente al espíritu práctico de Aristóteles y al platonismo ideal, está siempre latente el espíritu que animaba al Manco de Lepanto en una síntesis maravillosamente lograda.

Ante la Purísima de Murillo, recientemente rescatada de Francia por la actuación decidida de nuestro Caudillo, la promesa de colaborar para la proclamación dogmática de la Asunción de María y su mediación universal.

La visita terminó frente a un cuadro de Goya: "Los fusilamientos de la Moncloa". Pensamos en dos fechas: 1808 y 1936. En ambos el invasor extranjero, francesada, comunismo o masonería, lo mismo da, desangraban a una nación que con un perfecto espíritu misionero y heroico proclamó al musıdo en todo momento la verdad do la sentencia bíblica: "Militis est vita hominis super terram".

\section{Jaime Pereira Garcia,} nistración y Estudios Urbanos 